\title{
PENGARUH MODEL PEMBELAJARAN INQUIRY TRAINING TERHADAP HASIL BELAJAR SISWA PADA MATERI POKOK FLUIDA DINAMIS KELAS XI SEMESTER GENAP DI SMA NEGERI 2 BINJAI T.P. 2014/2015
}

\author{
Filza Sabila Mentaridan Ridwan Abdullah Sani \\ Jurusan Fisika FMIPA Universitas Negeri Medan \\ Filza.Sabila@gmail.com
}

\begin{abstract}
ABSTRAK
Telah dilakukan penelitian yang bertujuan untuk mengetahui pengaruh model pembelajaran inquiry trainingterhadap hasil belajar fisika dan keterampilan proses sains siswa di SMA Negeri 2 Binjai. Jenis penelitian ini adalah quasi eksperiment. Populasi dalam penelitian adalah seluruh siswa kelas XI yang terdiri dari 9 kelas. Pengambilan sampel dilakukan dengan cara cluster random sampling dengan mengambil 2 kelas, yaitu kelasXI PMS 2 sebagai kelas eksperimen dan kelas X PMS 3 sebagai kelas kontrol. Hasil penelitian menunjukkan nilai gain pengamatan keterampilan proses sains siswa adalah 0,62 dengan kategori sedang dengan rata-rata hasil belajar kelas eksperimen 85,44 dan di kelas kontrol 38,86. Dari hasil uji $t$ terdapat perbedaan akibat pengaruh penggunaan model pembelajaran inquiry trainingterhadap hasil belajar siswa. Antara hasil belajar dan keterampilan proses sains siswa didapat nilai koefisien sebesar 0,730 pada materi pokok Fluida Dinamis di kelas XI Semester SMA Negeri 2 Binjai T.P $2014 / 2015$.
\end{abstract}

Kata kunci : model pembelajaran inquiry training, hasil belajar, keterampilan proses sains siswa

\begin{abstract}
The aim of this research is to know the effect of inquiry training learning model on students' achievement and students' science process skillsin SMAN 2 Binjai. Kind of this research is experimental research. The population is all the students in grade XI which were consisted of 9 classes. The sample that the researchers used is cluster random sampling by taking 2 classes, that is XI PMS 2 as an experimental class and XI PMS 3 as a control class. The results show the value of the gain observational science process skills of students is 0.62 with category with the average results of experimental class learning 85.44 and 38.86 in the control class. From the results of $t$-test differences due to the effect of inquiry learning model training on student learning outcomes. Among the results of learning and science process skills students acquired coefficient value of 0.730 in the subject matter Fluid Dynamic in class XI SMA Semester 2 Binjai TP $2014 / 2015$.
\end{abstract}

Keywords : inquiry training learning model, students'achievement, students' science process skills 


\section{PENDAHULUAN}

Proses yang mendasar dalam aktivitas pendidikan di sekolah adalah proses pembelajaran yang menimbulkan interaksi antara peserta didik dan guru sehingga menambah kemampuan peserta didik untuk belajar untuk mencapai tujuan belajar. Pembelajaran fisika juga merupakan kegiatan pendidikan yang dirancang untuk memberikan pengalaman belajar yang melibatkan proses mental dan fisik melalui interaksi antar peserta didik, peserta didik dengan guru, lingkungan dan sumber belajar lainnya dalam mencapai kompetensi dasar.

Proses pembelajaran fisika hendaknya berisi kegiatan-kegiatan yang membuat siswa dapat mengembangkan kemampuankemampuan untuk memecahkan suatu masalah. Materi ajar saat ini belum menunjukkan relevansi yang tinggi dengan kebutuhan masyarakat. Ilmu fisika yang diterapkan di sekolah seakan akan tidak berdampak dalam cara hidup dan cara berpikir siswa dalam mengatasi permasalahan seharihari serta pembelajaran fisika masih berfokus pada kegiatan menghafal konsep, sehingga siswa merasa kesulitan dalam memahami konsep fisika.

Berdasarkan hasil observasi yang telah penulis lakukan di SMA Negeri 2 Binjai diperoleh data hasil belajar fisika siswa yang masih rendah yaitu rata-rata 70. Sedangkan Kriteria Ketuntasan Minimal (KKM) yang akan dicapai adalah 77. Dari hasil angket yang disebarkarkan pada Kelas XI-PMS 3 , ternyata dalam proses pembelajaran fisika $70 \%$ guru kadang-kadang menggunakan media atau alat peraga saat melakukan simulasi di depan kelas. Dalam proses pembelajaran di kelas guru mendominasi dengan lebih banyak $77,5 \%$ menjelaskan materi dengan menghubungkan terhadap pengalaman sehari-hari tetapi guru melakukan $55 \%$ pembelajaran dengan mencatat dan mengerjakan soal fisika, sehingga kurangnya kesempatan siswa untuk memiliki pengalaman belajar yang nyata dan aktif dan kegiatan praktikum pun jarang dilaksanakan dan mengakibatkan keterampilan proses siswa menjadi pasif dan kurang terbentuk. Hal tersebut menunjukkan bahwa proses pembelajaran berpusat pada guru (teacher center) atau cenderung mengutamakan keaktifan guru dibandingkan siswa sehingga keingintahuan siswa tentang fisika cukup rendah dan pembelajaran berlangsung hanya bersifat satu arah. Kekurangaktifan siswa tersebut dinyatakan dengan teknik belajar menghapal dari apa yang diterimanya, siswa menerima informasi dari guru tanpa harus siswa menemukan sendiri makna fisis dari konsep yang diajarkan.

Hasil belajar dalam penelitian ini lebih difokuskan pada karakteristik kompetensi keterampilan siswa. Hal ini sesuai dengan kurikulum 2013 yang menyatakan untuk mengetahui hasil belajar siswa harus berorientasi pada karakteristik kompetensi yaitu: ranah sikap, ranah keterampilan dan ranah pengetahuan. Jadi jenis keterampilan dalam penelitian ini adalah keterampilan proses sains, menurut Semiawan (2009) di kutip dari Fatmi (2014) keterampilan proses sains adalah keterampilan fisik dan mental terkait dengan kemampuankemampuan yang mendasar yang dimiliki, dikuasai, dan diaplikasikan dalam suatu kegiatan ilmiah, sehingga para ilmuan berhasil menemukan sesuatu yang baru. Untuk mengetahui realita permasalahan di sekolah lebih lanjut mengenai keterampilan proses sains, maka peneliti harus melihat proses pembelajaran yang berlangsung di sekolah tersebut. Menurut Haryono (2006) Menyatakan bahwa rendahnya kemampuan proses sains siswa setidaknya dapat dijelaskan dari aspek proses pembelajaran yang berlangsung 
dan dari aspek sistem penilaian yang dikembangkan oleh para guru.

Berdasarkan penelitian awal yang dilakukan dapat disimpulkan bahwa keterampilan proses sains siswa di sekolah masih rendah. Hal ini mengakibatkan kemampuan siswa seperti melakukan pengamatan, merumuskan hipotesis, menggunakan alat, mengumpulkan data, mengidentifikasi variabel, membuat kesimpulan dan kegiatan yang lain dapat mengembangkan keterampilan proses ilmiah yang ada pada diri siswa tidak tampak. Menurut Hosnan (2014) keterampilan proses adalah proses belajar mengajar yang menekankkan kepada keterampilan memperoleh pengetahuan dan mengkomunikasikan perolehannya itu.

Permasalahan di atas sebenarnya dapat diatasi jika guru dapat melihat permasalahanpermasalahan di kelas dan mencari model pembelajaran yang tepat untuk menyelesaikan masalah tersebut, agar materi pembelajaran dapat diserap dan dipahami siswa dengan baik dan siswa tidak kesulitan dalam menerima pelajaran. Salah satu model pembelajaran yang dapat meningkatkan hasil belajar siswa adalah model pembelajaran inquiry training.

Menurut Joyce dkk (2011) menyatakan, bahwa model pembelajaran inquiry training sebenarnya telah dikembangkan oleh Richard Suchman untuk mengajarkan siswa tentang proses dalam meneliti dan menjelaskan fenomena asing. Model ini menawarkan strategi penelitian, nilai-nilai, sikap-sikap yang penting dalam ranah penelitian yaitu Keterampilan mengolah (mengobservasi, mengumpulkan, dan mengolah data; mengidentifikasi dan mengontrol variabel; merumuskan dan menguji hipotesis dan penjelasan; menarik kesimpulan).

Melalui model pembelajaran inquiry training ini siswa diharapkan aktif mengajukan pertanyaan mengapa sesuatu terjadi kemudian mencari dan mengumpulkan serta memproses data secara logis untuk selanjutnya mengembangkan strategi intelektual yang dapat digunakan untuk menemukan jawaban atas pertanyaan mengapa sesuatu terjadi. Hal ini sesuai dengan teori Suchman dalam Joyce dkk (2011) yang menerapkan model pembelajaran dari fakta menuju teori atau from facts to teories. Selain itu, guru juga dapat menggunakan kesempatan ini untuk mengajarkan prosedur pengkajian sesuai dengan langkah-langkah model pembelajaran inquiry training.

Peneliti sebelumnya yang dilakukan oleh Komyadi (2014) diperoleh hasil penelitian dengan menunjukkan ada peningkatan aktivitas siswa pada fase pengumpulan data percobaan dan mengolah serta merumuskan suatu penjelasan dalam model pembelajaran inquiry training. Selain itu, penelitian yang dilakukan oleh Sirait (2010) diperoleh hasil penelitian dengan menunjukkan ada pengaruh terhadap hasil belajar siswa dengan menggunakan model pembelajaran inquiry training.

Adapun tujuan penelitian ini yaitu 1) Untuk mengetahui hasil belajar siswa setelah menggunakan model pembelajaran inquiry training, 2) Untuk mengetahui hasil belajar siswa setelah menggunakan model konvensional, 3) Untuk mengetahui keterampilan proses sains siswa dengan menggunakan model pembelajaran inquiry training, 4) Untuk mengetahui pengaruh model inquiry training terhadap hasil belajar siswa, 5) Untuk mengetahui hubungan hasil belajar dan keterampilan proses sains siswa dengan menggunakan model pembelajaran inquiry training.

\section{METODOLOGI PENELITIAN}

Penelitian ini telah dilaksanakan di Sekolah Menengah Atas Negeri 2 Binjai, Jln. Padang No.8 
Kelurahan Rambung Dalam, Kecamatan Binjai Selatan, Kotamadya Binjai. Waktu penelitian ini dilaksanakan pada 30 April sampai 30 Juni 2015.

Populasi dalam penelitian ini adalah siswa kelas XI pada Sekolah Menengah Atas Negeri 2 Binjai semester genap T.P 2014/2015 yang berjumlah 9 kelas. Pengambilan sampel dilakukan dengan teknik pengambilan sampel acak berkelompok (cluster random sampling), diambil 2 kelas yaitu kelas XI PMS 2sebagai kelas eksperimen diajarkan model pembelajaran inquiry training dan kelas XI PMS 3 sebagai kelas kontrol diajarkan dengan pembelajaran konvensional.

Jenis penelitian ini adalah quasi eksperiment (eksperimen semu).Desain penelitian ini adalah Group pre-testpost-test design.Desain penelitian ini dapat dilihat pada tabel 1 sebagai berikut.

Tabel 1.Pre-test and Post-test Group

\begin{tabular}{|l|c|c|c|}
\hline \multicolumn{1}{|c|}{ Kelas } & Pretes & Perlakuan & Postes \\
\hline Eksperimen & $\mathrm{O}$ & $\mathrm{Xa}$ & $\mathrm{O}$ \\
\hline Kontrol & $\mathrm{O}$ & $\mathrm{Xb}$ & $\mathrm{O}$ \\
\hline
\end{tabular}

(Arikunto, 2012)

Keterangan:

$\mathrm{Xa}=$ Pembelajaran dengan menerapkan model pembelajaraninquiry training.

$\mathrm{Xb}=$ Pembelajaran dengan menerapkan model pembelajaran konvensional.

$\mathrm{O}=$ Instrumen hasil belajar kognitif.

Pengumpulan data dalam penelitian ini dilakukan dengan metode observasi dan metode tes. Instrumen yang dipersiapkan yaitu perangkat pembelajaran, lembar pengamatan, tes hasil belajar berbentuk pilihan ganda 20 soal dan tes keterampilan proses sains berbentuk esaai dengan 20 soal. Sebelum data diolah menggunakan uji $\mathrm{t}$ untuk mengetahui pengaruh model pembelajaran inquiry trainingterlebih dahulu dilakukan penilaian pretes, uji normalitas (uji Lilliefors), uji homogenitas (uji F) dan uji kesamaan rata-rata pretes (uji t).

\section{HASIL DAN PEMBAHASAN}

Mengenai identifikasi hasil pretes dan postes, analisis dan pembahasan, uji hipotesis, uji korelasi, serta keterlaksanaan model pembelajaran inquiry training.

Berdasarkan tes hasil belajar yang telah dilakukan di SMA Negeri 2 Binjai diperoleh data pretes untuk kelas eksperimen dengan jumlah siswa 34 orang memperoleh nilai rata-rata sebesar 46,47 dengan nilai tertinggi 60 dan nilai terendah adalah 30 . Untuk kelas kontrol dengan jumlah siswa 35 orang memperoleh nilai rata-rata pretes sebesar 38,86 dengan nilai tertinggi 55 dan nilai terendah 20. Data yang diperoleh ditunjukkan pada tabel 2.

Tabel 2. Data Nilai Pretes Kelas Eksperimen dan Kelas Kontrol

\begin{tabular}{|c|c|c|c|c|c|}
\hline \multicolumn{3}{|c|}{$\begin{array}{c}\text { Data nilai pretes } \\
\text { kelas } \\
\text { eksperimen }\end{array}$} & \multicolumn{3}{|c|}{$\begin{array}{l}\text { Data nilai pretes } \\
\text { kelas kontrol }\end{array}$} \\
\hline Nilai & $\mathrm{F}_{\mathrm{i}}$ & $\begin{array}{c}\text { Rata } \\
- \\
\text { rata }\end{array}$ & Nilai & $\mathrm{F}_{1}$ & $\begin{array}{l}\text { Rat } \\
a^{-} \\
\text {rata }\end{array}$ \\
\hline \multirow{2}{*}{30} & \multirow{2}{*}{5} & \multirow{9}{*}{$\begin{array}{c}46,4 \\
7\end{array}$} & 20 & 2 & \multirow{9}{*}{$\begin{array}{c}38,8 \\
6\end{array}$} \\
\hline & & & 25 & 5 & \\
\hline 35 & 4 & & 30 & 2 & \\
\hline 40 & 2 & & 35 & 3 & \\
\hline 45 & 5 & & 40 & 9 & \\
\hline 50 & 7 & & 45 & 7 & \\
\hline 55 & 5 & & 50 & 6 & \\
\hline 60 & 6 & & 55 & 1 & \\
\hline \multicolumn{2}{|c|}{$\Sigma=34$} & & \multicolumn{2}{|c|}{$\Sigma=35$} & \\
\hline
\end{tabular}

Datapostes untuk kelas eksperimen dengan jumlah siswa 34 orang memperoleh nilai rata-rata postes sebesar 85,44 dengan nilai tertinggi adalah 100 dan nilai terendah adalah 60. Untuk kelas kontrol dengan jumlah siswa 35 orang memperoleh nilai rata-rata postes sebesar 57,29 dengan nilai tertinggi adalah 75 dan nilai terendah adalah 35. Data yang 
diperoleh ditunjukkan pada tabel 3 dibawah ini.

Tabel 3.Data Nilai Postes Kelas

Eksperimen dan Kelas Kontrol

\begin{tabular}{|c|c|c|c|c|c|}
\hline \multicolumn{3}{|c|}{$\begin{array}{l}\text { Data nilai postes } \\
\text { kelas eksperimen }\end{array}$} & \multicolumn{3}{|c|}{$\begin{array}{c}\text { Data nilai postes } \\
\text { kelas kontrol }\end{array}$} \\
\hline Nilai & $\mathrm{F}_{\mathrm{i}}$ & $\begin{array}{l}\text { Rata } \\
\text {-rata }\end{array}$ & $\mathrm{F}_{\mathrm{i}}$ & $\begin{array}{c}\text { Nila } \\
\text { i }\end{array}$ & $\begin{array}{l}\text { Rata } \\
\text {-rata }\end{array}$ \\
\hline 60 & 2 & \multirow{9}{*}{$\begin{array}{c}85,4 \\
4\end{array}$} & 35 & 1 & \multirow{9}{*}{$\begin{array}{c}75,7 \\
5\end{array}$} \\
\hline 65 & 1 & & & & \\
\hline 70 & 2 & & 45 & 5 & \\
\hline 75 & 2 & & 50 & 7 & \\
\hline 80 & 6 & & 55 & 6 & \\
\hline 85 & 7 & & 60 & 6 & \\
\hline 90 & 4 & & 65 & 3 & \\
\hline 95 & 1 & & 70 & 4 & \\
\hline 100 & 9 & & 75 & 3 & \\
\hline \multicolumn{2}{|c|}{$\Sigma=34$} & & \multicolumn{2}{|c|}{$\Sigma=35$} & \\
\hline
\end{tabular}

Dalam proses pengamatan keterampilan proses sains, observer (pengamat) memberikan tanda (tally) pada peristiwa yang muncul. Dalam pengumpulan data selama proses pembelajaran berlangsung yang berpedoman pada lembar pengamatan beserta rubrik penilaian yang sudah disiapkan oleh peneliti.

Pengamatan dilakukan pada kelas eksperimen berjumlah 34 orang, maka peneliti membagi siswa secara heterogen menjadi 5 kelompok. Pengamatan dilakukan selama kegiatan belajar mengajar yang terdiri dari empat kali pertemuan.

Data perkembangan keterampilan proses sains siswa di kelas eksperimen mengalami peningkatan selama menerima pembelajaran dengan menggunakan model pembelajaran inquiry trainingyaitu nilai gainketerampilan proses sains siswa dari pertemuanI dan II yaitu 0,44; pertemuan II dan III dengan gain 0,53 dan pertemuan III dan IV dengan gain 0,62 . Jadi, nilai gain keterampilan proses sains siswa selama pembelajaran di kelas eksperimen termasuk dalam kategori gain yang sedang.

Untuk melihat secara rinci perkembangan keterampilan proses sains siswa dapat dilihat pada diagram batang berikut:

Rata-rata Gain Keterampilan Proses Sains Kelas Eksperimen

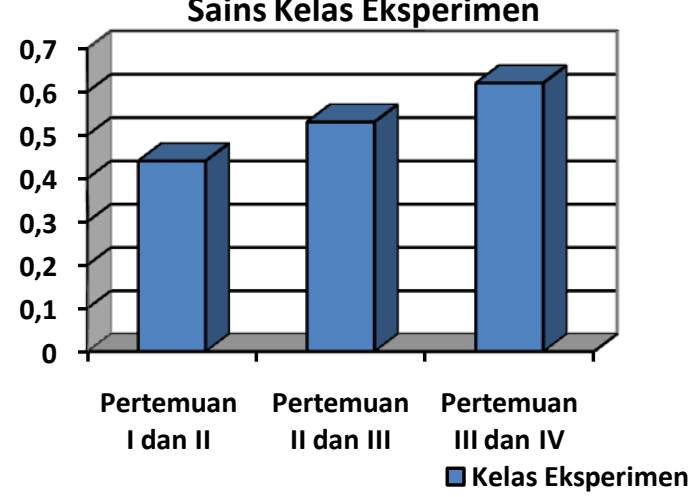

Gambar 1.Perkembangan Gain

Keterampilan Proses Sains Siswa di Kelas Eksperimen

Setelah kelas eksperimen diberikan perlakuan model pembelajaran inquiry training dan diberikan postes tes hasil belajar (kognitif), selanjutnya diberikan tes keterampilan proses sains (psikomotorik) yang terdiri dari 20 soal essay. Hasil yang diperoleh adalah seperti pada tabel 4.10 di bawah ini.

Tabel 4. Data Nilai Keterampilan Proses Sains Kelas Eksperimen

\begin{tabular}{|c|c|c|}
\hline \multicolumn{3}{|c|}{ Kelas Eksperimen } \\
\hline Kelas Interval & $\begin{array}{c}\text { Frekuens } \\
\text { i }\end{array}$ & $\begin{array}{c}\text { Rata- } \\
\text { rata }\end{array}$ \\
\hline $70-72$ & 6 & \multirow{2}{*}{79,97} \\
\hline $73-75$ & 6 & \\
\hline $76-78$ & 3 & \\
\hline $79-81$ & 3 & \\
\hline $82-84$ & 5 & \\
\hline $85-87$ & 5 & \\
\hline $88-90$ & 6 & \\
\hline \multicolumn{2}{|c|}{$\Sigma=34$} & \\
\hline
\end{tabular}

Setelah didapatkan data hasil belajar dan keterampilan proses sains siswa, selanjutnya di ukur keeratan hubungan antara keterampilan proses sains terhadap hasil belajar siswa menggunakan model pembelajaraninquiry training dengan uji korelasi person atau dikenal juga dengan korelasi product moment. Uji korelasi menggunakan bantuan program SPSS 15 for Windows. 
Setelah dilakukan pengolahan data, maka tampilan hasil uji korelasi product moment adalah seperti pada tabel dibawah:

Tabel 5. Hasil Uji Korelasi antara hasil belajar dan keterampilan proses sains Correlations

\begin{tabular}{|c|c|c|c|}
\hline & & Hasil & KPS \\
\hline \multirow[t]{3}{*}{ Hasil } & $\begin{array}{l}\text { Pearson } \\
\text { Correlation }\end{array}$ & 1 & $.730(* *)$ \\
\hline & Sig. (2-tailed) & & .000 \\
\hline & $\mathrm{N}$ & 34 & 34 \\
\hline \multirow[t]{4}{*}{ KPS } & Pearson & $.730{ }^{*}$ & \\
\hline & Correlation & *) & 1 \\
\hline & Sig. (2-tailed) & .000 & \\
\hline & $\mathrm{N}$ & 34 & 34 \\
\hline
\end{tabular}
ada hubungan antara keterampilan proses sains terhadap hasil belajar siswa yang diajarkan menggunakan model pembelajaran inquiry training. Korelasi antara hasil belajar dan keterampilan proses sains siswa didapat nilai koefisien sebesar 0,730. Karena koefisien mendekati 1 maka dapat disimpulkan bahwa antara hasil belajar dengan keterampilan proses sains siswa memiliki hubungan yang kuat dengan tingkat hubungan yang kuat yang berada di interval 0,60 0,799. Angka koefisien positif menunjukkan hubungan positif, yaitu jika keterampilan proses sains meningkat maka hasil belajar juga meningkat.

Hasil penelitian menunjukkan bahwa ada pengaruh yang signifikan menggunakan model pembelajaran inquiry training terhadap hasil belajar fisika pada materi pokok fluida dinamis kelas XI semester genap di SMA Negeri 2 Binjai T.P. 2014/2015. Hal ini diperkuat dengan adanya perbedaan peningkatan keterampilan proses sains siswa dan hasil belajar kelas eksperimen.

Penerapan model pembelajaran inquiry training ini didasarkan atas kelebihannya yang menekankan kepada pengembangan aspek kognitif dan aspek psikomotorik secara seimbang, sehingga pembelajaran melalui model ini dianggap lebih bermakna.

Sebelum diberikan pembelajaran yang berbeda kepada masing-masing kelas terlebih dahulu dilakukan tes awal (pretest) untuk mengetahui kemampuan awal siswa pada materi pokok fluida dinamis sebelum diberikan perlakuan pembelajaran. Hasil penelitian diperoleh rata-rata nilai pretes siswa kelas yang terpilih sebagai kelas eksperimen adalah sebesar 46,47 dengan standar deviasi 10,34. Sedangkan untuk kelompok siswa yang terpilih sebagai kelas kontrol diperoleh rata-rata nilai pretes sebesar 38,86 dengan standar deviasi 9,63. Berdasarkan hasil menunjukkan bahwa tidak ada perbedaan yang signifikan (nyata) kemampuan awal kedua kelompok siswa dan hasil ini juga menunjukkan bahwa nilai rata-rata kemampuan awal siswa masih tergolong rendah sebelum diterapkan perlakuan.

Setelah diketahui bagaimana kemampuan awal para siswa dilakukan pembelajaran yang berbeda. Pada kelas eksperimen diberi perlakuan dengan model pembelajaran inquiry training. Pada akhir pembelajaran siswa diberikan postes untuk mengetahui bagaimana hasil belajar kedua kelompok siswa setelah diberkan perlakuan. Hasil penelitian menunjukkan rata-rata nilai postes siswa yang diajarkan dengan model pembelajaran inquiry training (kelas eksperimen) adalah sebesar 85,44 dengan standar deviasi 11,89. Sedangkan siswa yang diajarkan dengan model pembelajaran konvensional (kelas kontrol) diperoleh rata-rata nilai postes 57,29 dengan standar deviasi10,17. Ini membuktikan hasil belajar siswa yang menggunakan model pembelajaran inquiry training lebih tinggi dari pada pembelajaran konvensional. 
Selama pelaksanaan penelitian diperoleh bahwa model pembelajaran inquiry training menguntungkan karena memberi peluang yang sama kepada semua siswa, baik siswa yang memiliki kemampuan rendah, sedang ataupun tinggi untuk berhasil.

Demikian juga berdasarkan hasil penelitian dan pengujian hipotesis dapat dilihat bahwa dengan menerapkan model pembelajaran inquiry training dapat meningkatkan hasil belajar siswa dan lebih baik dibandingkan hasil belajar siswa yang diajarkan dengan model pembelajaran konvensional. Hal tersebut dapat dilihat dari nilai rata-rata postest kelas eksperimen yaitu 85,44 sedangkan rata-rata postest kelas kontrol yaitu 57,29 . Sehingga dapat disimpulkan bahwa Ada pengaruh model pembelajaran inquiry training terhadap hasil belajar fisika pada materi pokok fluida dinamis kelas XI semester genap di SMA Negeri 2 Binjai T.P. 2014/2015. Hal ini didukung oleh Harahap dan Sinuraya (2013) yang menyatakan bahwa ada pengaruh signifikan penggunaan model pembelajaran inquiry training dengan nilai rata-rata postes kelas eksperimen yaitu 70,375 dan kelas kontrol yaitu 63,125 . Hal ini juga didukung oleh penelitian sebelumnya salah satunya yaitu Setiawan (2014) dengan nilai rata-rata postes kelas eksperimen yaitu 73,4 dan kelas kontrol yaitu 59,2.

Selama pelaksanaan penelitian diperoleh bahwa model pembelajaran inquiry training menguntungkan karena dapat mendorong siswa untuk mengembangkan disiplin intelektual dan keterampilan yang mampu meningkatkan pertanyaan-pertanyaan dan pencarian jawaban yang terpendam dari rasa keingintahuan siswa. Siswa juga menjadi lebih terampil dalam ekspresi verbal seperti mendengarkan pendapat orang lain dan mengingat apa yang telah diutarakan.

$\begin{array}{ccr}\text { Model } & \text { pembelajaran } & \text { inquiry } \\ \text { training } & \text { membantu } & \text { dan }\end{array}$

mengembangkan "self-concept" pada diri siswa, sehingga siswa dapat mengerti tentang konsep dasar dan ideide lebih baik, mendorong siswa untuk berfikir dan bekerja atas inisiatifnya sendiri, bersikap objektif, jujur dan terbuka, Ini terlihat pada saat siswa belajar dalam kelompok, siswa saling berdiskusi dalam mengerjakan dan memecahkan permasalahan yang ada pada LKS dan menjawab pertanyaan yang diajukan oleh guru.

Pada dasarnya tujuan utama penelitian ini adalah untuk mengetahui pengaruh model pembelajaran inquiry training terhadap hasil belajar fisika. Namun, tugas yang diberikan kepada setiap kelompok berupa lembar kegiatan siswa maka perlu dilakukan pencatatan terhadap pengamatan keterampilan proses sains siswa selama kegiatan pembelajaran. Pencatatan terhadap pengamatan keterampilan proses sains siswa ini bertujuan untuk mengetahui seberapa besar keaktifan siswa selama kegiatan belajar mengajar berlangsung.

Dari hasil pengamatan yang dilakukan observer diperoleh bahwa keterampilan proses sains siswa mengalami peningkatan yang positif. Pada pertemuanI dan II gain keterampilan proses sains siswa diperoleh sebesar 0,44. Hal ini terjadi karena siswa belum terbiasa dengan model pembelajaran inquiry training hingga instruksi dan motivasi yang diberikan peneliti kurang dimengerti oleh beberapa siswa. Oleh karena itu, peneliti terus memberikan instruksi dan arahan kepada siswa hingga siswa paham dan termotivasi melaksanakan tugas kelompok dan tanggung jawab mereka dalam pembelajaran ini.

Pada pertemuan II dan III, diperoleh peningkatan yang positif terhadap keterampilan proses sains siswa dengan nilai gain 0,53 dan pertemuan III dan IV diperoleh gain keterampilan proses sains 0,62. Berdasarkan hasil pengamatan tersebut menunjukkan bahwa model 
pembelajaran inquiry training dapat meningkatkan keterampilan proses sains di kelas eksperimen. Hal ini didukung oleh pendapat Joice, et all., (2011), yang menyatakan bahwa format model pembelajaran inquiry training menawarkan keterampilan mengolah data serta pembelajaran yang aktif dan otonom, terutama saat siswa merumuskan masalah dan menganalisis data.

Penelitian ini juga dilakukan oleh Komyadi (2014), penerapan media simulasi PhET untuk meningkatkan aktivitas siswa dalam model pembelajaran inquiry training. Hal ini ditunjukkan dari nilai rata-rata aktivitas siswa menggunakan pengamatan keterampilan proses sains pada siklus I 66,38 dan pada siklus II 81,74 dengan $\mathrm{N}$-gain 45,69\% (kategori sedang).

Terdapat juga hubungan (korelasi) antara tes hasil belajar dan keterampilan proses sains siswa didapat nilai koefisien sebesar 0,730. Karena koefisien mendekati 1 maka dapat disimpulkan bahwa antara hasil belajar dengan keterampilan proses sains siswa memiliki hubungan yang erat. Angka koefisien positif menunjukkan hubungan positif, yaitu jika keterampilan proses sains meningkat maka hasil belajar juga meningkat.

Peningkatan hasil belajar menggunakan model pembelajaran inquiry traininglebih baik disebabkan model pembelajaran inquiry trainingini dapat memotivasi siswa untuk lebih aktif saat pelaksanaan proses pembelajaran. Pada saat siswa belajar dalam kelompok, siswa saling berdiskusi dalam mengerjakan dan memecahkan permasalahan yang ada pada LKS dan menjawab pertanyaan yang diajukan oleh guru pada materi fluida dinamis terlihat siswa aktif dalam mengambil peran dalam pelaksanaannya. Selain itu, siswa lebih terdorong untuk berfikir intuitif dan merumuskan hipotesisnya sendiri.
Beberapa temuan penelitian
yang relevean dengan temuan penelitian ini antara lain adalah Sirait (2010) terdapat pengaruh pada hasil belajar siswa dengan menggunakan model pembelajaran inquiry training. Hal ini ditunjukan dari nilai rata-rata pretes belajar siswa yang diajar sebesar 4,29 dan hasil postes sebesar 6,29. Sedangkan pada model pembelajaran konvensional nilai rata-rata pretes siswa sebesar 4,03 dan postes sebesar 5,64. Disamping itu, aktivitas belajar siswa yang diajar dengan menggunakan model pembelajaran inquiry training diperoleh skor 67,38 dengan kategori aktif. Sucita dan Simanjuntak (2013), menyimpulkan bahwa hasil belajar siswa yang mendapat perlakuan model pembelajaran inquiry training lebih tinggi $(75,43)$ daripada hasil belajar kelompok siswa yang mendapat perlakukan metode konvensional $(64,42)$.

Peningkatan hasil belajar menggunakan model pembelajaran inquiry traininglebih baik disebabkan model pembelajaran inquiry trainingini dapat memotivasi siswa untuk lebih aktif saat pelaksanaan proses pembelajaran. Pada saat siswa belajar dalam kelompok, siswa saling berdiskusi dalam mengerjakan dan memecahkan permasalahan yang ada pada LKS dan menjawab pertanyaan yang diajukan oleh guru pada materi fluida dinamis terlihat siswa aktif dalam mengambil peran dalam pelaksanaannya. Selain itu, siswa lebih terdorong untuk berfikir intuitif dan merumuskan hipotesisnya sendiri.

Penggunaan

model pembelajaran inquiry training dapat meningkatkan hasil belajar dan keterampilan proses sains siswa, tetapi selama pembelajaran masih terkendala masih adanya siswa yang kurang serius di setiap kelompok pada saat eksperimen karena anggota dalam kelompok sedikit lebih banyak. Mengatasi hal ini, upaya yang dilakukan adalah sebaiknya jumlah 
siswa dalam setiap kelompok cukup 3-4 orang saja agar semua siswa bekerja dalam setiap kelompok dan tidak banyak bicara.

\section{KESIMPULAN DAN SARAN}

$\begin{array}{ccl}\text { Dari } & \text { hasil } & \text { analisis yang } \\ \text { dilakukan dalam } & \text { penelitian ini }\end{array}$ diperoleh kesimpulan nilai rata-rata pretes kelas eksperimen sebesar 46,47 dan nilai rata-rata postes pada kelas eksperimen sebesar 85,44. Diberikan perlakuan di kelas eksperimen denganmodel pembelajaran inquiry trainingdan kelas kontrol denganpembelajaran konvensional.

Selama proses pembelajaran, nilai gain pengamatan keterampilan proses sains siswa adalah 0,62 dengan kategori sedang. Sedangkan nilai ratarata pretes kelas kontrol sebesar38,86 dan nilai rata-rata postes pada kelas kontrol yang diajarkan dengan pembelajaran konvensional sebesar 57,29. Dari hasil uji hipotesis dengan menggunakan uji t, ada perbedaan hasil belajar siswa yang diajarkan dengan model pembelajaran inquiry trainingmateri pokok fluida dinamisdi kelas XI semester Genap SMA Negeri 2 Binjai T.P 2014/2015 T.P 2014/2015, dengan kata lain bahwa model pembelajaran inquiry trainingmemberikan pengaruh yang signifikan dalam meningkatkan hasil belajar siswa. Terdapat juga hubungan antara hasil belajar dan keterampilan proses sains siswa didapat nilai koefisien sebesar 0,730.

Berdasarkan hasil dan
kesimpulan dalam penelitian ini, maka peneliti mempunyai beberapa saran. Bagi para peneliti selanjutnya yang ingin menggunakan model pembelajaran inquiry training sebaiknya mempersiapkan masalahmasalah dalam kehidupan sehari-hari yang menarik dan terkait pada materi pelajaran sehingga siswa akan tertarik mengikuti pelajaran.

Bagi guru dan para peneliti selanjutnya agar mempertimbangkan aspek sarana dan prasarana yang memadai untuk menuntun siswa berpikir logis dan sistematis tentang konsep serta penyesuaian materi belajar dan waktu belajar yang tersedia agar model ini dapat berjalan dengan baik dan lancar.

\section{DAFTAR PUSTAKA}

Arikunto, S., (2012), Dasar-dasar Evaluasi Pendidikan, Bumi Aksara, Jakarta.

Fatmi, N., (2014), Pengaruh Model Pembelajaran Inkuiri Terbimbing dan Kreativitas Terhadap Keterampilan Proses Sains Siswa SMAN 1 Julok., Tesis, Pascasarjana, Unimed, Medan.

Harahap, F., dan Sinuraya, J., (2013), Pengaruh Model Pembelajaran Inquiry Training Terhadap Hasil Belajar Siswa Pada Materi Pokok Suhu dan Pengukuran Kelas VII Semester I MTs N 2 Medan, Jurnal INPAFI 1 : 34-40.

Haryono., (2006), Model Pembelajaran Berbasis Peningkatan Keterampilan Proses Sains, Jurnal Pendidikan Dasar (7): 1-13.

Hosnan., (2014), Pendekatan Saintifik dan Kontekstual dalam Pembelajaran Abad 21 Kunci Sukses Implementasi Kurikulum 2013, Ghalia Indonesia, Yogyakarta.

Joyce, B.; Weil, M. \& Calhoun, E., (2011), Model-Model Pembelajaran, Edisi Delapan, Pustaka Belajar, Yogyakarta.

Komyadi., (2014), Penerapan Media Simulasi PhET (Physics Education Technology) Untuk Meningkatkan Aktivitas Siswa Pada Fase Pengumpulan Data Percobaan dan Mengolah serta Merumuskan Suatu Penjelasan Dalam Model Pembelajaran Inquiry Training di SMA Negeri 5 Takengon, Tesis, Pascasarjana, Unimed, Medan.

Setiawan, R., (2014), Pengaruh Model Pembelajaran Latihan Inkuiri 
(Inquiry Training Model) Berbasis Peta Konsep Terhadap Hasil Belajar Siswa Pada Materi Zat dan Wujudnya di Kelas VII Semester I Yayasan Taman Pendidikan SMP Daya Cipta Medan T.P. 2013/2014, Skripsi, FMIPA, Unimed, Medan.

Sirait, R., (2012), Pengaruh Model Pembelajaran Inquiry Training Terhadap Hasil Belajar Siswa
Pada Materi Pokok Usaha dan Energi Kelas VIII Semester I MTs N 3 Medan, , Jurnal Pendidikan Fisika $1: 21-26$.

Sucita, E., dan Simanjuntak, M.P., (2013), Pengaruh Model Pembelajaran Inquiry Training Terhadap Hasil Belajar FisikaSiswa SMA Negeri 1 Percut Sei Tuan, Jurnal INPAFI 1 : 143153. 
Jurnal Inpafi

Volume 3 Nomor 4 Nopember 2015 